\title{
Kompleksitas Pajak, Moral Wajib Pajak dan Norma Subyektif Terhadap Kepatuhan Perpajakan
}

\author{
Yordan Ediantoro Dharmawan1, Priyo Hari Adi ${ }^{2}$ \\ 1,2 Universitas Kristen Satya Wacana, Salatiga, Indonesia
}

\begin{abstract}
Keywords:

Complexity;

Morals;

Subjective

Norms;

Taxation

Kata kunci:

Kompleksitas;

Moral;

Abstract: National development requires financing from both domestic and foreign. The amount of contribution made by MSMEs to GDP can increase state revenues through MSME taxes. Tax compliance is needed in increasing the awareness of MSME owners regarding taxation. The purpose of this study is to analyze tax complexity, taxpayer morale and subjective norms affect tax compliance. This type of research is descriptive quantitative, using the method of explanation. The population of this study is the owners of SMEs. The sampling technique used online survey. Sampling using non-probability Sampling using convenience. The number of samples is 66 people. Methods of data collection using a questionnaire. The analysis technique uses descriptive quantitative statistics using multiple regression. The results showed that the significance value of tax complexity was $0.018<0.05$, so tax complexity had a positive effect on tax compliance. The value of the taxpayer's moral significance is $0.021<0.05$, then the taxpayer's morale has a positive effect on tax compliance. The significance value of subjective norms is $0.016<0.05$, so subjective norms have a positive effect on tax compliance. So, it can be concluded that partially tax complexity, taxpayer morale and subjective norms affect tax compliance. The implications of this research are expected to provide benefits in an effort to increase the awareness of MSME owners regarding taxation.
\end{abstract}

Norma

Subyektif;

Perpajakan

\section{Alamat Korespondensi:}

Abstrak: Pembangunan nasional memerlukan pembiayaan, baik dari dalam negeri maupun luar negeri Besarnya kontribusi yang diberikan oleh UMKM terhadap PDB dapat meningkatkan penerimaan negara melalui pajak UMKM. Kepatuhan perpajakan diperlukan dalam meningkatkan kesadaran pemilik UMKM mengenai perpajakan. Tujuan penelitian ini untuk menganalisis kompleksitas pajak, moral wajib pajak, dan norma subjektif berpengaruh terhadap kepatuhan perpajakan. Jenis penelitian ini adalah menggunakan deskriptif kuantitatif dengan menggunakan metode eksplanasi. Populasi penelitian ini adalah pemilik UMKM. Teknik pengambilan sampel menggunakan online survey. Pengambilan sampel dengan menggunakan nonprobability sampling dengan menggunakan menggunakan convenience. Jumlah sampel sebanyak 66 orang. Metode pengumpulan data menggunakan kuesioner. Teknik analisis menggunakan statistik deskriptif kuantitatif dengan menggunakan regresi berganda. Hasil penelitian menunjukkan nilai signifikansi kompleksitas pajak 0,018<0,05, maka kompleksitas pajak berpengaruh positif atas kepatuhan perpajakan. Nilai signifikansi moral wajib pajak sebesar $0,021<0,05$, maka moral wajib pajak berpengaruh positif atas kepatuhan perpajakan. Nilai signifikansi norma subjektif sebesar $0,016<0,05$, maka norma subjektif berpengaruh positif atas kepatuhan perpajakan. Dapat disimpulkan bahwa bahwa secara parsial kompleksitas pajak, moral wajib pajak, dan norma subjektif berpengaruh atas kepatuhan perpajakan. Implikasi penelitian ini diharapkan dapat memberikan manfaat dalam upaya meningkatkan kesadaran pemilik UMKM mengenai perpajakan.

E-mail: 232014168@student.uksw.edu (Dharmawan)

\section{Pendahuluan}

Indonesia merupakan negara berkembang yang memiliki kekayaan sumber daya melimpah dan berpotensi untuk menjadi negara maju (Mulyati Akib, Ika Maya Sari, 2017; Sriniyati, 2020; Suari \& Rasmini, 2018). Pembangunan ekonomi negara manapun bergantung pada jumlah pendapatan

$\begin{array}{ll}\text { History: } & \\ \text { Received } & \text { : 20 Mei } 2021 \\ \text { Revised } & : 23 \text { Mei } 2021 \\ \text { Accepted } & : \text { 20 Juni } 2021 \\ \text { Published } & : 25 \text { Juli } 2021\end{array}$

Publisher: Undiksha Press

Licensed: This work is licensed under a Creative Commons Attribution 3.0 License

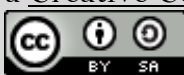


yang dihasilkan untuk penyediaan infrastruktur dan pelayanan sosial. Pembangunan nasional memerlukan pembiayaan baik dari dalam negeri maupun luar negeri (Theo et al., 2018). Penerimaan dari dalam negeri harus terus ditingkatkan dan digali untuk membantu melaksanakan pembangunan nasional, salah satunya mengoptimalkan penerimaan dari sektor pajak (Astuti \& Panjaitan, 2018; Suari \& Rasmini, 2018). Pajak adalah iuran kepada negara (dapat dipaksakan) untuk membiayai pengeluaran-pengeluaran umum berhubungan dengan tugas negara yang menyelenggarakan pemerintahan (Broto, 2017; Syakura \& Baridwan, 2014; Tanilasari \& Gunarso, 2017). Pajak memiliki peranan yang begitu penting, sehingga mendorong pemerintah untuk melakukan berbagai upaya strategis untuk memaksimalkan penerimaan pajak.

Berdasarkan RAPBN Indonesia tahun 2019, pendapatan Indonesia mencapai Rp 2.165,1 triliun. Dari pendapatan tersebut sektor perpajakan menyumbang $84 \%$ dari total penerimaan tersebut. Penerimaan pajak ini dikarenakan adanya kontribusi Usaha Mikro, Kecil ,dan Menengah (UMKM). Besarnya kontribusi yang diberikan oleh UMKM terhadap PDB dapat meningkatkan penerimaan negara melalui pajak UMKM (Nurlinda \& Sinuraya, 2020). Oleh sebab itu, untuk meningkatkan dari penerimaan negara terutama dari pajak UMKM, diperlukan peran aktif dari pemerintah. Salah satunya yaitu dengan membuat PP No. 46 tahun 2013 mengenai pajak penghasilan dari usaha yang diperoleh WP yang memiliki peredaran bruto tertentu, terutama mengenai ketentuan perpajakan pada UMKM (Puspitasari, 2019). Upaya meningkatkan penerimaan pajak pada UMKM diperlukan kepatuhan perpajakan (Astuti \& Panjaitan, 2018; Nurizzaman, 2020; Putra, 2020). Kepatuhan perpajakan diperlukan dalam meningkatkan kesadaran pemilik UMKM mengenai perpajakan. Kepatuhan pajak merupakan kewajiban dari WP dalam melaksanakan perpajakannya (Putra, 2020; Tanilasari \& Gunarso, 2017). Mengukur kepatuhan WP UMKM ada dua hal yang perlu diketahui yaitu kapatuhan formal dan kepatuhan material (Aruan et al., 2017; Astuti \& Panjaitan, 2018). Kepatuhan formal yaitu WP memiliki kewajiban kewajiban dalam memotong pendapatannya yang nantinya disetor sebagai pajak, wajib mendaftarkan diri sebagai WP, wajib mengisi SPT, serta membuat catatan maupun pembukuan usaha (Agustin et al., 2020; Putra, 2020). Kapatuhan material meliputi WP mengisi formulir dari pajak dengan baik dan benar serta mengitung pajak pendapatan dengan baik dan benar (Sugawara \& Nikaido, 2014).

Faktor yang dapat memengaruhi kepatuhan perpajakan pada UMKM adalah kompleksitas perpajakan (Novriyanti \& Dalam, 2020). Temuan penelitian sebelumnya menyatakan bahwa kompleksitas pajak memengaruhi kepatuhan pajak pada UMKM (Mulyani \& Purnomo, 2019; Wiyarni et al., 2019). Hal ini berarti bahwa kompleksitas sistem administrasi pajak yang mudah akan dapat meningkatkan kepatuhan WP dengan menerapkan anjuran dari pihak petugas pajak. Hal yang berbeda dengan penelitian sebelumnya yang menemukan kompleksitas pajak tidak memengaruhi kepatuhan pajak (Syakura dan Baridwan, 2014). Dengan adanya kompleksitas peraturan perpajakan, maka wajib pajak diharuskan untuk mengetahui peraturan perpajakan dengan cara mempelajari peraturan tersebut sehingga dengan bertambahnya pengetahuan wajib pajak maka akan meningkatkan kepatuhan wajib pajak dalam memenuhi kewajiban perpajakannya tanpa mengeluhkan kesulitan dalam memahami peraturan perpajakan (Agustina, 2016; Sugawara \& Nikaido, 2014). Hal ini menunjukkan bahwa perlunya upaya wajib pajak untuk mengetahui dengan seksama dan menyeluruh terhadap undang-undang perpajakan yang diberlakukan di Indonesia. WP yang menggunakan moral didalam kepatuhan pajak memiliki tingat kepatuhan yang berbeda (Sudirman et al., 2020). Namun WP yang menggunakan moral yang baik akan memiliki kepatuhan yang tinggi dalam membayar pajak (Andriyani et al., 2018). Adanya pengaruh moral wajib pajak terhadap kepatuhan perpajakan berarti bahwa dengan semakin tinggi moral wajib pajak dapat meningkatkan kepatuhan perpajakan pada UMKM (Andriyani et al., 2018; Aruan et al., 2017).

Selain kompleksitas dan moral wajib pajak, norma subjektif muncul karena adanya dorongan dari orang lain seperti keluarga, saudara, teman, dan pihak-pihak lain yang ada kaitanya dengan pajak seperti konsultan pajak dan petugas pajak yang ikut serta memengaruhi kepatuhan pajak pada WP (Sanita et al., 2018; Sudirman et al., 2020). Kepatuhan seseorang terhadap aturan perpajakan tidak hanya dipengaruhi oleh diri wajib pajak, tetapi dari lingkungan atau dari individu lain. Pihakpihak tersebut disebut sebagai pihak pemberi acuan (Sanita et al., 2018). Temuan penelitian Faisal \& 
Yulianto (2019), Priliandani \& Saputra (2019) dan (Karwur et al., 2020) menemukan adanya pengaruh norma subjektif terhadap terhadap kepatuhan perpajakan. Norma subjektif merupakan pengaruh dari orang-orang yang dianggap penting di sekitar (dalam hal ini misalnya teman, konsultan pajak, atau petugas pajak) yang ikut membentuk kepatuhan pajak dari wajib pajak tersebut (Faisal \& Yulianto, 2019; Karwur et al., 2020; Priliandani \& Saputra, 2019). Sehingga apabila orang-orang tersebut memiliki sikap positif terhadap kepatuhan pajak, maka WP tersebut akan memiliki perilaku kepatuhan yang positif pula. Tujuan penelitian ini yaitu untuk menganalisis pengaruh kompleksitas pajak, moral wajib pajak dan moral subyektif terhadap kepatuhan perpajakan.

\section{Metode}

Jenis penelitian ini adalah deskriptif kuantitatif dengan menggunakan metode eksplanasi, yaitu variabel-variabel yang ada dalam penelitian ini diolah dan hasilnya dijelaskan secara jelas mengenai pengaruh antara masing-masing variabel. Populasi penelitian ini adalah pemilik UMKM. Teknik pengambilan sampel menggunakan online survey. Pengambilan sampel dengan menggunakan nonprobability. Teknik sampling menggunakan convenience sampling merupakan pengambilan sampel didasarkan pada ketersediaan dan kemudahan untuk mendapatkannya. Kemudahan dalam hal ini yaitu kesediaan responden dalam mengisi kuesioner secara online. Jumlah sampel pada penelitian ini sebanyak 66 orang pemilik UMKM. Responden pada penelitian ini sebagian besar dengan jenis kelamin laki-laki sebesar $62,12 \%$ dengan usia terbanyak adalah usia di atas 45 tahun sebesar $46,97 \%$. Tingkat pendidikan sebagian besar responden berpendidikan terakhir adalah SMA sebesar $56,06 \%$. Adapun jenis usaha terbanyak adalah perdagangan seperti toko sebesar 57,58\%Berdasarkan omset per tahun sebgian besar beromset per tahun kurang dari 300 juta. Hal ini berarti bahwa UMKM yang menjadi responden termasuk dalam kategori usaha mikro. Metode pengumpulan data menggunakan kuesioner.

Tabel 1. Konsep, Definisi Konsep dan Indikator Empirik

\begin{tabular}{|c|c|c|}
\hline Variabel & Konsep Dan Definisi & Indikator Empirk \\
\hline $\begin{array}{l}\text { Kepatuhan } \\
\text { perpajakan }\end{array}$ & $\begin{array}{l}\text { Sebagai suatu keadaan wajib } \\
\text { pajak memenuhi semua } \\
\text { kewajiban perpajakan dan } \\
\text { melaksanakan } \\
\text { perpajakannya (Rahayu, 2010). }\end{array}$ & $\begin{array}{l}\text { 1) wajib pajak memiliki kewajiban melakukan } \\
\text { pemotongan atau pemungutan pajak, } \\
\text { 2) Kewajiban untuk mendaftarkan diri, } \\
\text { 3) Kewajiban mengisi dan menyampaikan Surat } \\
\text { Pemberitahuan, } \\
\text { 4) Kewajiban membayar atau menyetor pajak, } \\
\text { 5) Kewajiban membuat pencatatan. } \\
\text { 6) Kewajiban menaati pemeriksaan pajak. } \\
\text { 7) Wajib pajak mengisi formulir pajak dengan } \\
\text { bena. } \\
\text { 8) Menghitung jumlah pajak dengan benar. }\end{array}$ \\
\hline $\begin{array}{l}\text { Kompleksitas } \\
\text { pajak }\end{array}$ & $\begin{array}{l}\text { Kompleksitas perpajakan } \\
\text { adalah suatu kondisi ketika } \\
\text { wajib pajak tidak memahami } \\
\text { isi, pengertian maupun } \\
\text { prosedur yang di atur dalam } \\
\text { administrasi perpajakan } \\
\text { (Forest dan Sheffrin, 2002). }\end{array}$ & $\begin{array}{l}\text { 1) Tingkat kesulitan/ kerumitan formulir } \\
\text { administrasi pajak. } \\
\text { 2) Tingkat kesulitan/ kerumitan undang- } \\
\text { undang dan peraturan pajak. } \\
\text { 3) Kelengkapan instruksi formulir administrasi } \\
\text { pajak. } \\
\text { 4) Frekuensi perubahan peraturan pajak }\end{array}$ \\
\hline $\begin{array}{l}\text { Moral Wajib } \\
\text { pajak }\end{array}$ & $\begin{array}{l}\text { Motivasi intrinsik untuk } \\
\text { bertindak jujur dan mematuhi } \\
\text { perpajakan serta membayar } \\
\text { pajak yang dilakukan oleh }\end{array}$ & $\begin{array}{l}\text { 1) Melanggar etika, } \\
\text { 2) Perasaan bersalah, } \\
\text { 3) Prinsip hidup } \\
\text { 4) Melanggar prosedur }\end{array}$ \\
\hline
\end{tabular}




\begin{tabular}{lll}
\hline \multicolumn{1}{c}{ Variabel } & \multicolumn{1}{c}{ Konsep Dan Definisi } & \multicolumn{1}{c}{ Indikator Empirk } \\
\hline \multirow{3}{*}{ Norma } & wajib pajak (Torgler, 2007). & \\
subyektif & Norma yang dimiliki oleh Dorongan keluarga dan teman, konsultan pajak, & individu yang berasal dari petugas pajak, media cetak/media elektronik \\
& rujukan orang lain tentang untuk mematuhi ketentuan perpajakan. \\
& perilaku mereka setuju atau & \\
& membiarkan penggelapan \\
& pajak (Cahyonowati, 2017). & \\
\hline
\end{tabular}

Uji validitas digunakan untuk mengukur keabsahan masing-masing indikator dalam tiap variabel. Indikator dikatakan valid jika nilai $r$ hitung $>0,3$. Setelah dilakukan uji validitas, selanjutnya dilakukan uji reliabilitas untuk mengetahui kekonsistenan setiap item pertanyaan yang tercantum dalam kuesioner serta jawaban dari responden. Uji reliabilitas dilakukan dengan metode Cronbach Alpha. Berdasarkan uji validitas diperoleh nilai Item-Total Correlation tiap indikator lebih besar dari 0,3 dengan alpha $5 \%$. Artinya, data valid dan dapat dianalisis lebih lanjut. Hasil uji reliabilitas berdasarkan pada nilai Cronbach Alpha $(\alpha)$, memenuhi unsur reliabilitas dengan nilai Cronbach Alpha $(\alpha)$ lebih besar dari 0,60 (Ghozali, 2012). Dengan demikian, maka dapat digunakan dalam pengolahan data selanjutnya.

Teknik analisis menggunakan analisis kuantitatif dengan pengujian asumsi klasik untuk mengetahui data yang digunakan telah memenuhi ketentuan dalam model regresi atau tidak sebelum melakukan pengujian regresi. Pengujian asumsi klasik ini meliputi Uji normalitas dan uji heteroskedastisitas. Uji Normalitas yang digunakan untuk mengetahui variabel dependen maupun independen mempunyai distribusi secara nomal atau tidak normal. Salah satu cara yang digunakan untuk menguji kenormalan adalah uji kolmogrov smirnov. Apabila nilai probabilitas uji ini lebih besar dari 5\% $(0,05)$, maka model regresi berdistribusi normal. Uji heteroskedastisitas berguna untuk mengetahui apakah dalam uji yang digunakan yaitu uji regresi berganda terjadi ketidaksamaan residual dalam pengamatan. Uji ini menggunakan uji Glejser. Jika nilai signifikansi $>0,05$ maka data tidak terjadi masalah heteroskedastisitas. Pengujian hipotesis dalam penelitian ini dilakukan dengan menggunakan uji $r$ square, uji $F$ dan uji t. Uji R square $\left(R^{2}\right)$ yaitu seberapa besar kemampuan variabel independen dalam menjelaskan variabel dependen. Sedangkan pada uji $\mathrm{F}$ apabila nilai signifikansi < 0,05 , maka variabel independen berpengaruh signifikan terhadap variabel dependen. Tujuan penggunaan uji $t$ adalah untuk mengetahui berpengaruh atau tidaknya variabel independen secara parsial terhadap variabel dependen. Apabila nilai signifikansi $<0,05$, maka dapat dikatakan bahwa secara parsial variabel independen berpengaruh signifikan terhadap variabel dependen.

\section{Hasil dan Pembahasan}

Hasil

Berdasarkan hasil analisis, uji normalitas dalam penelitian dengan menggunakan uji kolmogoronov Smirnov diperoleh nilai signifikansi sebesar 0,385 >0,05. Hal tersebut berarti bahwa data dapat dikatakan normal. Berdasarkan uji heteroskedastisitas diperoleh nilai signifikansi untuk variabel kompleksitas pajak sebesar 0,83, moral wajib pajak sebesar 0,362, dan moral subjektif sebesar 0,436. Karena signifikansi tersebut lebih besar dari 0,05, maka dapat dikatakan tidak ada masalah heteroskedastisitas. Pengaruh kompleksitas pajak, moral wajib pajak, dan moral subjrktif terhadap kepatuhan perpajakan diketahui hasilnya pada tabel 2. sebagai berikut.

Tabel 2. Hubungan kompleksitas pajak, moral wajib pajak, dan moral subjektif terhadap kepatuhan perpajakan

\section{Model Summary}

\begin{tabular}{ccccc}
\hline Model & $\mathbf{R}$ & R Square & Adjusted R Square & Std. Error of the Estimate \\
\hline 1 & 0,342 & 0,431 & 0,452 & 3,171 \\
\hline
\end{tabular}


Nilai R-Square pada hasil ini menunjukkan nilai sebesar 0.452 . Nilai ini mengandung arti bahwa pengaruh kompleksitas pajak, moral wajib pajak, dan moral subjektif terhadap kepatuhan perpajakan sebesar $42,5 \%$, sisanya sebesar $57,5 \%$ dipengaruhi oleh variabel lain di luar model penelitian. Syarat hubungan antarvariabel baik atau tidak bila nilai R-Square di atas $50 \%$ artinya baik dan jika di bawah $50 \%$ artinya belum baik. Berdasarkan hasil tersebut, dapat dikatakan bahwa pengaruh kompleksitas pajak, moral wajib pajak, dan moral subjektif terhadap kepatuhan perpajakan dapat dikatakan belum baik.

Tabel 3. Uji F kompleksitas pajak, moral wajib pajak, dan moral subjektif terhadap kepatuhan perpajakan

\begin{tabular}{llccccc}
\hline \multicolumn{7}{c}{ ANOVA } \\
\hline \multirow{2}{*}{ Model } & & Sum of & & & & \\
\hline 1 & Squares & Df & Mean Square & F & Sig. \\
\hline & Regression & 7,537 & 2 & 13,004 & 5,998 & 0,003 \\
& Residual & 2,674 & 64 & 10,178 & & \\
& Total & 10,211 & 66 & & & \\
\hline
\end{tabular}

Berdasarkan Tabel 3 tersebut, dapat dijelaskan bahwa nilai signifikansi uji $F$ sebesar 0,003. Nilai tersebut lebih kecil dari 0,05. Artinya, variabel kompleksitas pajak, moral wajib pajak, dan moral subjektif secara bersama-sama berpengaruh terhadap kepatuhan perpajakan.

Tabel 4. Uji t kompleksitas pajak, moral wajib pajak, dan moral subjektif terhadap kepatuhan perpajakan

\begin{tabular}{llccccc}
\hline \multicolumn{7}{c}{ Coefficients } \\
\hline & \multicolumn{2}{c}{$\begin{array}{c}\text { Unstandardized } \\
\text { Coefficients }\end{array}$} & $\begin{array}{c}\text { Standardized } \\
\text { Coefficients }\end{array}$ & & \\
\cline { 2 - 5 } Model & B & Std. Error & Beta & T & Sig. \\
\hline $1 \quad$ (Constant) & 22,553 & 3,875 & 0,384 & 5,819 & 0,000 \\
& Kompleksitas Pajak & 0,483 & 0,091 & 0,397 & 3,123 & 0,018 \\
& Moral Wajib Pajak & 0,363 & 0,074 & 0,372 & 2,952 & 0,021 \\
$\quad$ Norma Subyektif & 0,452 & 0,083 & 0,463 & 3,274 & 0,016 \\
\hline
\end{tabular}

Berdasarkan data pada tersebut dapat dijelaskan nilai signifikansi kompleksitas pajak $0,018<0,05$, maka kompleksitas pajak berpengaruh positif atas kepatuhan perpajakan. Nilai signifikansi moral wajib pajak sebesar $0,021<0,05$, maka moral wajib pajak berpengaruh positif atas kepatuhan perpajakan. Nilai signifikansi norma subjektif sebesar $0,016<0,05$, maka norma subyektif berpengaruh positif atas kepatuhan perpajakan.

\section{PEMBAHASAN}

Hasil penelitian menunjukkan bahwa adanya pengaruh kompleksitas pajak terhadap kepatuhan perpajakan. Temuan pertama menunjukkan adanya kompleksitas pajak berpengaruh positif atas kepatuhan perpajakan. Kompleksitas perpajakan adalah kesulitan atau kerumitan dalam memahami peraturan perpajakan yang dijumpai dalam undang-undang perpajakan dan peraturan pelaksanannya yang dituangkan dalam Peraturan Pemerintah, Keputusan Menteri Keuangan dan Surat Edaran Direktorat Jenderal Pajak (Wiyarni et al., 2019). Temuan ini diperkuat dengan penelitian sebelumnya yang menemukan kompleksitas pajak berpengaruh terhadap kepatuhan pajak (Agustina, 2016; Devos, 2012; Nurizzaman, 2020; Putra, 2020; Sugawara \& Nikaido, 2014). Hal ini berarti bahwa 
semakin kompleks sistem perpajakan akan semakin menurunkan kepatuhan perpajakan WP. Dengan adanya kompleksitas peraturan perpajakan, maka wajib pajak diharuskan untuk mengetahui peraturan perpajakan dengan cara mempelajari peraturan tersebut. Dengan bertambahnya pengetahuan wajib pajak akan meningkatkan kepatuhan wajib pajak dalam memenuhi kewajiban perpajakannya tanpa mengeluhkan kesulitan dalam memahami peraturan perpajakan (Mulyani \& Purnomo, 2019; Wiyarni et al., 2019). Namun, adanya kompleksitas pajak membuat WP semakin enggan dalam mematuhi perpajakan. Hal ini menunjukkan bahwa perlunya upaya wajib pajak mengetahui dengan seksama dan menyeluruh undang-undang perpajakan yang diberlakukan di Indonesia.

Temuan kedua menunjukkan adanya pengaruh moral wajib pajak terhadap kepatuhan perpajakan. Moral wajib pajak berpengaruh positif atas kepatuhan perpajakan. Setiap wajib pajak yang memiliki moral yang baik dengan cara pandang positif terhadap pajak serta menganggap pajak itu sebagai suatu kewajiban yang positif akan meningkatkan kepatuhan wajib pajak untuk memenuhi semua kewajiban perpajakannya (Andriyani et al., 2018; Suari \& Rasmini, 2018). Hasil penelitian sejalan dengan penelitian sebelumnya yang menemukan adanya pengaruh moral wajib pajak terhadap kepatuhan perpajakan (Aruan et al., 2017; Astuti \& Panjaitan, 2018). Hal ini berarti bahwa semakin baik moral wajib pajak akan meningkatkan kepatuhan perpajakan. Moral pajak merupakan kunci dari penjelasan mengapa WP jujur dalam masalah perpajakan (Astuti \& Panjaitan (2018). Wajib pajak yang mempunyai kesadaran moral yang baik sebagai warga negara dalam melaksanakan kewajiban pajaknya berbeda dengan warga negara yang tidak mempunyai kesadaran moral (Andriyani et al., 2018). Dengan demikian, aspek moralitas wajib pajak akan meningkatkan kecenderungan wajib pajak dalam memenuhi kewajiban pajaknya WP yang menggunakan moral d idalam kepatuhan pajak memiliki tingat kepatuhan yang berbeda (Aruan et al., 2017).

Temuan ketiga menunjukkan norma subjektif berpengaruh positif atas kepatuhan perpajakan. Hasil penelitian sejalan dengan penelitian sebelumnya yang menemukan adanya pengaruh norma subjektif terhadap terhadap kepatuhan perpajakan (Faisal \& Yulianto, 2019; Karwur et al., 2020; Priliandani \& Saputra, 2019). Norma subjektif merupakan pengaruh dari orang-orang yang dianggap penting di sekitar (dalam hal ini misalnya teman, konsultan pajak, atau petugas pajak) yang ikut membentuk kepatuhan pajak dari wajib pajak tersebut (Karwur et al., 2020; Sani, 2016). Apabila orang-orang tersebut memiliki sikap positif terhadap kepatuhan pajak, maka wajib pajak tersebut akan memiliki perilaku kepatuhan yang positif pula. Norma subjektif muncul karena adanya dorongan dari orang lain seperti keluarga, saudara, teman, dan pihak-pihak lain yang ada kaitanya dengan pajak seperti konsultan pajak dan petugas pajak yang ikut serta memengaruhi kepatuhan pajak pada wajib pajak (Sanita et al., 2018). Kepatuhan seseorang terhadap aturan perpajakan tidak hanya dipengaruhi oleh diri wajib pajak itu sendiri, akan tetapi dari lingkungan atau dari individu lain. Pihak-pihak tersebut disebut sebagai pihak pemberi acuan (Sanita et al., 2018).

\section{Simpulan}

Secara parsial kompleksitas pajak, moral wajib pajak dan norma subjektif berpengaruh atas kepatuhan perpajakan. Secara simultan kompleksitas pajak, moral wajib pajak, dan norma subjektif bersama-sama berpengaruh atas kepatuhan perpajakan. Moral wajib pajak merupakan variabel yang paling rendah dalam mepengaruhi kepatuhan perpajakan UMKM. Oleh sebab itu, guna meningkatkan moral wajib pajak diharapkan pihak KPP dan pemerintah untuk memotivasi para pelaku usaha akan pentingnya perpajakan. Keterbatas penelitian ini yaitu terkendala dengan responden karena terkait dengan covid 19 . Selain itu juga pada saat pencarian data secara langsung responden kebanyakan menolak. Direkomendasikan untuk penelitian yang akan datang diharapkan untuk menambahkan variabel lain di luar model penelitian. Implikasi penelitian ini diharapkan dapat memberikan dampak pada upaya meningkatkan kepatuhan perpajakan. 


\section{Daftar Pustaka}

Agustin, A. W., Darmansyah, \& Suyanto. (2020). Kepatuhan, Pemeriksaan, Penagihan, dan PenerimaantTerhadap Pajak dengan Peran Account Representative sebagai Pemoderasi. Jurnal Riset Akuntansi \& Perpajakan (JRAP), 7(01), 79-94., 7(01), 79-94. https://doi.org/10.35838/jrap.2020.007.01.8.

Agustina, K. A. (2016). Pengaruh Tingkat Pendidikan, Tingkat Penghasilan, dan Tarif Pajak terhadap Kepatuhan Wajib Pajak UMKM dalam Memenuhi Kewajiban Perpajakan (Studi Empiris Pelaku Umkm di Kabupaten Buleleng). Jurnal Akuntansi Profesi, 6(1), 1-11. https://doi.org/10.23887/jap.v6i1.21078.

Andriyani, J. E., Sitawati, R., \& Subchan, S. (2018). Pengaruh Moral Wajib Pajak Orang Pribadi terhadap Persepsi atas Tax Evasion dengan Kepatuhan Wajib Pajak sebagai Variabel Mediasi. Indonesian Journal of Accounting and Governance, 2(2), 35-68. https://doi.org/10.36766/ijag.v2i2.31.

Aruan, R., Sujana, E., Luh, N., \& Erni, G. (2017). The Influence of Taxpayer Attitudes, Taxpayer Morals, and Willingness to Pay Individual Taxes at the Tax Office (KPP) Pratama Gianyar. E-Journal S1 Ak Universitas Pendidikan Ganesha, 8(2), 1-10.

Astuti, T., \& Panjaitan, I. (2018). Pengaruh Moral Wajib Pajak dan Demografi Wajib Pajak terhadap Kepatuhan Wajib Pajak UMKM dengan Sanksi Perpajakan Sebagai Pemoderasi. Media Akuntansi Perpajakan; Publikasi Oleh Fakultas Ekonomi Dan Bisnis Universitas 17 Agustus 1945 Jakarta, 3(1), 58-73. http://journal.uta45jakarta.ac.id/index.php/MAP.

Broto, A. H. K. (2017). Pengaruh Kualitas Informasi Akuntansi Manajemen, Efektivitas Administrasi Perpajakan, dan Kepatuhan Wajib Pajak melalui Pengambilan Keputusan Manajemen terhadap Penerimaan Pajak Daerah. Jurnal Riset Akuntansi Terpadu, 10(2), 204-222. https://doi.org/10.35448/jrat.v10i2.4250.

Devos, K. (2012). The Impact of Tax Professionals upon the Compliance Behavior of Australian Individual Taxpayers. Revenue Law Journal, 22(1). https://doi.org/10.53300/001c.6730.

Faisal, M., \& Yulianto, A. (2019). Religiusitas, Norma Subjektif, dan Persepsi Pengeluaran Pemerintah dalam Mendukung Kepatuhan Wajib Pajak. Jurnal Kajian Akuntansi, 3(2), 170. https://doi.org/10.33603/jka.v3i2.3106.

Karwur, J. M., Sondakh, J. J., \& Kalangi, L. (2020). Pengaruh Sikap terhadap Perilaku, Norma Subjektif, Kontrol Perilaku yang Dipersepsikan dan Kepercayaan pada Pemerintah terhadap Kepatuhan Wajib Pajak Orang Pribadi dengan Niat sebagai Variabel Intervening ( Survey Pada KPP Pratama Manado ). Jurnal Riset Akuntansi Dan Auditing "GOODWILL", 11(2), 113-130. https://doi.org/10.35800/jjs.v11i2.30417.

Mulyani, S. D., \& Purnomo, T. H. (2019). Peran Kompleksitas Tugas dalam Hubungan Kompetensi, Independensi, dan Etika Pemeriksa Pajak dengan Kualitas Hasil Pemeriksaan. Jurnal Bisnis Dan Manajemen, 9(1), 109 - 118. https://doi.org/10.15408/ess.v9i1.13146.

Mulyati Akib, Ika Maya Sari, A. (2017). Pengaruh Tanggung Jawab Moral dan Kualitas Pelayanan terhadap Kepatuhan Pelaporan Wajib Pajak Badan (Studi pada Kantor Pelayanan Pajak Pratama Kendari). Jurnal Akuntansi Dan Keuangan, 2(2), 73-85. https://doi.org/10.33772/jak-uho.v2i2.2981.

Novriyanti, I., \& Dalam, W. W. W. (2020). Faktor-Faktor yang Memengaruhi Penghindaran Pajak. Journal of Applied Accounting and Taxation, 5(1), 24-35. https://doi.org/10.33633/jpeb.v5i1.2645.

Nurizzaman, R. (2020). Analisis Kepatuhan Perpajakan Pelaku Usaha Mikro, Kecil, dan Menengah (UMKM) di Indonesia: Studi pada Kota Banjarbaru Kalimantan Selatan. Jurnal IImiah Ekonomi Bisnis, 6(2), 176-185. https://doi.org/10.35972/jieb.v6i2.345.

Nurlinda, N., \& Sinuraya, J. (2020). Potensi Pajak pada Usaha Mikro Kecil Menengah (UMKM). Ekonomikawan: Jurnal Ilmu Ekonomi Dan ..., 20(2), 126-141. http://jurnal.umsu.ac.id/index.php/ekawan/article/view/5200.

Priliandani, N. M. I., \& Saputra, K. A. K. (2019). Pengaruh Norma Subjektif dan Sosialisasi Perpajakan 
terhadap Kepatuhan Wajib Pajak Hotel dan Restoran. Jurnal Kumpulan Riset Akuntansi, 11(1), 13-25. https://doi.org/10.22225/kr.11.1.\%y.13-25>.

Puspitasari, R. D. (2019). Persepsi Wajib Pajak Atas PP No.46 Tahun 2013 tentang Pajak Penghasilan dengan Peredaran Bruto Tertentu. Jurnal Analisa Akuntansi Dan Perpajakan, 2(2), 42-53. https://doi.org/10.25139/jaap.v2i2.1169.

Putra, A. F. (2020). Kepatuhan Wajib Pajak UMKM: Pengetahuan Pajak, Sanksi Pajak, dan Modernisasi Sistem. Jurnal Riset Akuntansi \& Perpajakan (JRAP), 7(01), 1-12. https://doi.org/10.35838/jrap.v7i01.1212.

Sani, A. (2016). Pengaruh Moral Wajib Pajak, Sikap Wajib Pajak, dan Norma Sujektif terhadap Kepatuhan Pajak melalui Pemahaman Akuntansi. Encyclopedia of Systems Biology, 5(2), 1646-1646. http://journals.synthesispublication.org/index.php/ilman.

Sanita, N., Yasa, I., \& Atmadja, A. (2018). Pengaruh Norma Subjektif terhadap Kepatuhan Wajib Pajak dalam Membayar Pajak Kendaraan Bermotor (Studi Empiris pada Kantor Bersama SAMSAT Kabupaten Buleleng). Jurnal IImiah Mahasiswa Akuntansi) Universitas Pendidikan Ganesha, 9(1), 2614-1930. https://doi.org/10.23887/jimat.v9i1.20475.

Sriniyati, S. (2020). Pengaruh Moral Pajak, Sanksi Pajak, dan Kebijakan Pengampunan Pajak terhadap Kepatuhan Pajak Wajib Pajak Orang Pribadi. Jurnal Akuntansi, Ekonomi Dan Manajemen Bisnis, 8(1), 14-23. https://doi.org/10.30871/jaemb.v8i1.1913.

Suari, N. L. E. V., \& Rasmini, N. K. (2018). Pemahaman Peraturan, Efektivitas Sistem, Kewajiban Moral, Kualitas Pelayanan, Sanksi Perpajakan pada Kemauan Ikut Tax Amnesty. E-Jurnal Akuntansi Universitas Udayana, 22(1), 108-137. https://doi.org/10.24843/EJA.2018.v22.i01.p05.

Sudirman, S. R., Lannai, D., \& Hajering. (2020). Pengaruh Norma Subjektif, Kewajiban Moral dan Pemahaman Peraturan Pajak terhadap Kepatuhan Wajib Pajak Pada KPP Pratama Makassar Utara. Amnesty: Jurnal Riset Perpajakan, 3(2), 164-190. https://doi.org/10.26618/jrp.v3i2.4412.g2896.

Sugawara, E., \& Nikaido, H. (2014). Properties of AdeABC and AdelJK Efflux Systems of Acinetobacter Baumannii Compared with Those of the AcrAB-TolC System of Escherichia Coli. Antimicrobial Agents and Chemotherapy, 58(12), 7250-7257. https://doi.org/10.1128/AAC.03728-14.

Syakura, M. A., \& Baridwan, Z. (2014). Determinan Perencanaan Pajak dan Perilaku Kepatuhan Wajib Pajak Badan. Jurnal Akuntansi Multiparadigma, 5(2). https://doi.org/10.18202/jamal.2014.08.5017.

Tanilasari, Y., \& Gunarso, P. (2017). Analisis Pengaruh Kesadaran Wajib Pajak dan Kualitas Pelayanan Fiskus terhadap Kepatuhan Wajib Pajak Orang Pribadi pada Kantor Pelayanan Pajak Pratama Malang Selatan. Jurnal Akuntansi Dan Perpajakan, 3(1), 1-9. https://doi.org/10.26905/ap.v3i1.1324.

Theo, J., Pangemanan, S., \& Walandouw, S. K. (2018). Analisis Penerimaan dan Bagi Hasil Pajak Kendaraan Bermotor pada Dinas Pendapatan Daerah Provinsi Sulawesi Utara. Going Concern: Jurnal Riset Akuntansi, 14(1), 523-529. https://doi.org/10.32400/gc.13.04.21413.2018.

Wiyarni, Hartini, \& Djuharni, D. (2019). Pengaruh Kompleksitas Peraturan Perpajakan, Kualitas Layanan, Sanksi Perpajakan, dan Pemeriksaan terhadap Kepatuhan Pajak. Jurnal Akuntansi Kontemporer, 10(1), 14-23. https://doi.org/10.33508/jako.v10i1.2190. 